\title{
EFFECT OF PULSED ELECTRIC FIELDS ON THE AMINO ACID COMPOSITION OF WHOLE MILK
}

\author{
R. Svyatnenko, A. Ukrainets, A. Marynin, O. Kochubei-Lytvynenko \\ National University of Food Technologies \\ M. Boyko \\ National Technical University "Kharkiv Polytechnic Institute"
}

\begin{tabular}{l}
\multicolumn{1}{c}{ Key words: } \\
Pulsed Electric Fields \\
Whole (raw) milk \\
Amino acids \\
\hline \multicolumn{1}{c}{ Article history: } \\
Received 15.01.2018 \\
Received in revised form \\
01.02.2018 \\
Accepted 12.02.2018 \\
\hline
\end{tabular}

Corresponding author:

R. Svyatnenko

E-mail:

Svyatnenko@i.ua

\begin{abstract}
The article is devoted to the study of the nature of the impact of pulsed electric fields (PEP) on the amino acid composition of whole milk.

Biological value of protein is characterized by the rate of its amino-acid composition and its need in organism to synthesize the protein. Protein substances, which do not include at least one of the vital amino acids, contain them in very small quantities, cannot ensure normal activity of the organism, are classified as inferior. That is why while determinating milk nutrition value one must consider first of all in what measure the quantitative ratio of essential and nonessential amino acids, present in milk is close to optimal ratio, determined by international WHO organization and general correlation of essential and nonessential amino acids. In examples received from the researched groups of pigs the increase of nonessential amino-acids synthesis has been discovered. By exceeding the permissible titer, the microorganisms of QMAFAnM and CGB can cause damage to the finished product and even food poisoning.

Object of investigation: pulsed electric fields. Subject of the study: whole milk before and after treatment with pulsed electric fields.

It has been established that by the treatment of whole milk with strong pulsed electric fields (PEP) with tensities range of 10 to $50 \mathrm{kV} / \mathrm{cm}$ with a total processing time in a stationary working chamber, taking into account pauses between impulses, up to 30 seconds inclusive, milk contains all essential amino acids.

During the study it was founded, that the dominant amino acid is lysine, while the limiting group is meteonin + cystine. As a result of the amino acid composition of the studied samples with the reference protein comparison, utilization factor was calculated, which is 1.25 and 1.23 . It has been proved that processing of PEP does not significantly affect the amino acid composition of raw milk to be treated, this treatment shows a slight decrease in the content of all amino acids, but its biological value corresponds to medical and biological requirements.
\end{abstract}

DOI: $10.24263 / 2225-2924-2018-24-1-16$ 


\section{ВПЛИВ ІМПУЛЬСНИХ ЕЛЕКТРИЧНИХ ПОЛІВ НА АМІНОКИСЛОТНИЙ СКЛАД НЕЗБИРАНОГО МОЛОКА}

\section{Р.С. Святненко, А.І. Українець, А.І. Маринін, О.В. Кочубей-Литвиненко Наиіональний університет харчових технологій}

М.I. Бойко

Національний технічний університет «Харківський політехнічний інститут»

Стаття присвячена дослідженню характеру впливу імпульсних електричних полів (ІЕП) на амінокислотний склад незбираного (сирого) молока.

Біологічна иінність білка характеризується ступенем відповідності його амінокислотного складу потребам організму в амінокислотах для синтезу білка. Білкові речовини, до складу яких не входить хоча б одна з життєво необхідних амінокислот чи міститься їх у дуже незначній кількості, що не може забезпечити нормальну діяльність організму, належать до неповноиінних. 3 огляду на ие при визначенні харчової иінності молока враховували насамперед, якою мірою кількісне співвідношення незамінних амінокислот, що міститься в ньому, наближається до оптимального, визначеного міжнародною комісією ФАО/ВООЗ, а також сумарне співвідномення незамінних $i$ замінних амінокислот.

Об'єкт дослідження: імпульсні електричні поля. Предмет дослідження: амінокислотний склад незбираного молока до та після оброблення імпульсними електричними полями.

Оброблення незбираного молока здійснювали на експериментальній установиі, що складається з трансформатора, іскрових розрядників, ємнісних нагромаджувачів енергї, системи керування, робочої камери.

Встановлено, що при обробленні незбираного молока сильними імпульсними електричними полями (IЕП) з напруженостями в діапазоні від 10 до 50 кB/см при загальній тривалості обробки в стаціонарній робочій камері, враховуючи паузи між імпульсами, до 30 с включно молоко містить усі незамінні амінокислоти.

У ході досліджень з'ясовано, що домінуючою амінокислотою є лізин, а лімітуючою - група метеонін + цистин. У результаті порівняння амінокислотного складу досліджуваних зразків з еталонним білком було розраховано коефіиієнт утилітарності, який становить 1,25 і 1,23. Доведено, що обробка ІЕП суттєво не впливає на амінокислотний склад сирого молока, щяо підлягає обробиі. При такій обробиі спостерігається незначне зниження вмісту всіх амінокислот, але при цъьому його біологічна иінність відповідає медикобіологічним вимогам.

Ключові слова: імпульсні електричні поля, незбиране (сире) молоко, амінокислоти.

Постановка проблеми. Серед продуктів харчування значне місце належить рідким харчовим продуктам: безалкогольним напоям, пиву, молоку, натуральним винам тощо. 
Відомі технології подовження термінів зберігання цих продуктів базуються на термічному обробленні (пастеризація та стерилізація), застосуванні ультрафільтрації, добавках до продукту різних за своєю природою хімічних консервантів. При цьому харчові й органолептичні властивості рідких харчових продуктів суттєво погіршуються [1].

Перспективним напрямом підвищення термінів зберігання цих продуктів $\epsilon$ застосування електрофізичних методів - сильних імпульсних електричних полів без розрядів.

Наведеним напрямкам досліджень присвячені праці М.I. Бойка [2-4], в яких представлено опис ІЕП-технології (або КВІД-технології, де КВІД комплекс високовольтних імпульсних дій), експериментальних установок і камер різних типів для реалізації цієї технології. Деякі результати досліджень щодо оброблення рідких харчових продуктів за допомогою КВІД представлено в [5]. Автори [6] стверджують, що імпульсна обробка дає змогу зберігати харчову і біологічну цінність дослідних зразків порівняно 3 традиційною тепловою пастеризації, а тим більше високотемпературної стерилізацією. Результати досліджень [7] показали, що дія IЕП при напруженості $\approx 30$ кВ/см протягом 30 с забезпечує значний ступінь інактивації кишкової палички Escherichia coli.

Метою дослідження $є$ визначення амінокислотного складу і біологічної цінності незбираного молока, обробленого сильними імпульсними електричними полями.

Матеріали і методи. Одним із важливих компонентів коров'ячого молока $\epsilon$ його білок, що являє собою джерело з високою біологічною цінністю. Він поділяється на казеїни (казеїнат кальцію) і сироваткові білки (альбуміни і глобуліни).

3 хімічної точки зору білки - це високомолекулярні сполуки, що складаються з різних амінокислот. Амінокислоти молока добре збалансовані та засвоюються практично повністю. Вони виконують функцію «будівельних блоків», з яких будується білкова структура організму, беруть участь в утворенні нуклеїнових кислот, ліпідів, гормонів.

Незамінні амінокислоти (ізолейцин, лізин, лейцин, фенілаланін, метіонін, треонін, валін і триптофан) не можуть утворюватися в організмі дорослої людини з інших амінокислот і безпосередньо надходять в організм людини тільки з їжею.

При проведенні досліджень використовувалася експериментальна установка, розроблена фахівцями в НТУ «Харківський політехнічний інститут», електрична схема якої наведена на рис. 1. Характеристики установки представлені в табл. 1.

Незбиране молоко 3 початковою температурою $(22 \pm 2){ }^{\circ} \mathrm{C}$ обробляли в стаціонарній камері закритого типу об'ємом $150 \mathrm{~cm}^{3}$. У робочу камеру впродовж 10-30 с здійснювалася подача енергії через іскрові розрядники. Напругу на робочій камері 3 оброблюваним продуктом (сирим молоком) реєстрували цифровим осцилографом фірми Rigol зі смугою пропускання 100 МГц. 


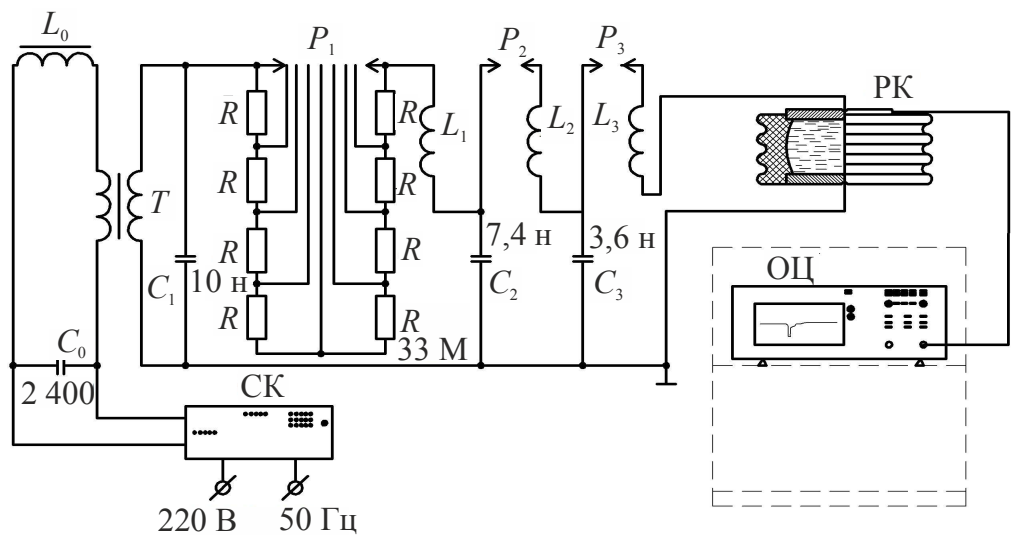

Рис. 1. Схема експериментальної установки для обробки рідких продуктів сильними імпульсними електричними полями: $L_{o}$ - дросель на броньовому магнітопроводі 3 еквівалентним перерізом $100 \cdot 90 \mathrm{Mм} ; T$ - трансформатор ИОМ-100/100; $L_{1}-L_{3}$ - паразитні індуктивності контурів; $P_{1}-P_{3}-$ іскрові розрядники; $C_{1}-C_{3}-$ ємнісний нагромаджувач енергії; $C_{0}$ - батарея конденсаторів; СК - система керування; СППУР - система підготовки, перекачування і упаковки рідин; ОЦ - осцилограф; РК — робоча камера

\section{Табличя 1. Характеристики установки}

\begin{tabular}{|c|c|}
\hline Напруга на ємнісних нагромаджувачах, кВ енергії, кВ & до 100 \\
\hline Частота проходження імпульсів, імп/с & до 400 \\
\hline Напруженість імпульсного електричного поля, кВ/см & до 100 \\
\hline Тривалість імпульсу, мкс & $\sim 1$ \\
\hline Тривалість фронту імпульсів, нс & $\sim 30$ \\
\hline Середня потужність генератора, кВт & 50 \\
\hline Орієнтовний ресурс генератора, кількість імпульсів & $10^{10} \ldots 10^{11}$ \\
\hline
\end{tabular}

Аналіз осцилограми, яка наведена на рис. 2, показує, що амплітуда напруги на робочій камері складає $\approx 30$ кВ, напруженість електричного поля в робочій камері $(\mathrm{PK}) \approx 20$ кВ/см, а тривалість фронту імпульсу $\approx 35$ нс.

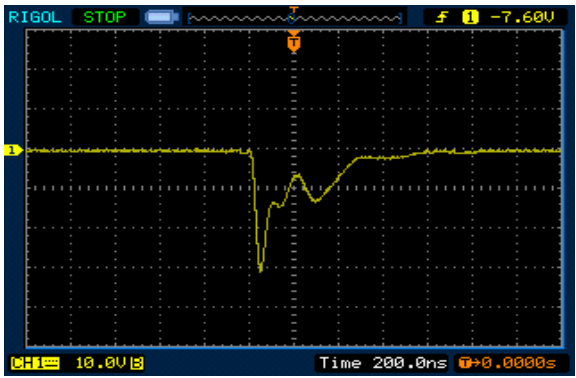

Рис. 2. Типова осцилограма напруги на РК з оброблюваним молоком

Напруженості електричного поля $E_{m}$ в робочій камері визначали за методом [2].

Амінокислотний склад білків визначали на автоматичному аналізаторі амінокислот Т339 виробництва «Мікротехна», Чехія. 
Результати і обговорення. Результати досліджень амінокислотного складу обробленого молока представлені в табл. 2

Таблиця 2. Амінокислотний склад обробленого молока

\begin{tabular}{|c|c|c|c|c|}
\hline \multirow{2}{*}{ Назва показника } & \multicolumn{2}{|c|}{ Вміст у контролі } & \multicolumn{2}{c|}{ Вміст в обробленому молоці } \\
\cline { 2 - 5 } & $\begin{array}{c}1 \text { мг/100г } \\
\text { продукту }\end{array}$ & $\begin{array}{c}1 \mathrm{Mг} / 1 \Gamma \\
\text { білка }\end{array}$ & $\begin{array}{c}1 \text { мг/100г } \\
\text { продукту }\end{array}$ & $\begin{array}{c}1 \text { мг/1г } \\
\text { білка }\end{array}$ \\
\hline Лізин & 232 & 79,73 & 220 & 75,60 \\
\hline Треонін & 141 & 48,45 & 140 & 48,11 \\
\hline Метіонін & 70 & 24,05 & 64 & 21,99 \\
\hline Цистеїн & 29 & 9,97 & 27 & 9,28 \\
\hline Валін & 152 & 52,23 & 146 & 50,17 \\
\hline Ізолейцин & 148 & 50,86 & 123 & 42,27 \\
\hline Лейцин & 207 & 71,13 & 203 & 69,76 \\
\hline Тирозин & 165 & 56,70 & 133 & 45,70 \\
\hline Фенілаланін & 100 & 34,36 & 94 & 32,30 \\
\hline Триптофан & 32 & 11,00 & 30 & 10,31 \\
\hline
\end{tabular}

Досліджено вміст кожної амінокислоти та встановлено незначні зниження вмісту амінокислот в оброблювальному зразку. У табл. 3 представлено вміст незамінних амінокислот обробленого молока порівняно з ідеальним білком за шкалою ФАО/ВОЗ [8].

Таблиця 3. Амінокислотний склад обробленого молока порівняно з ідеальним білком

\begin{tabular}{|c|c|c|c|}
\hline Найменування незамінної & \multicolumn{3}{|c|}{ Вміст НАК, мг / 1 г в молоці } \\
\cline { 2 - 4 } амінокислоти (НАК) & Ідеальний білок & Контроль & Оброблене молоко ІЕП \\
\hline Лізин & 55,00 & 79,73 & 75,60 \\
\hline Треонін & 40,00 & 48,45 & 48,11 \\
\hline Метіонін+цистин & 35,00 & 34,02 & 30,57 \\
\hline Валін & 50,00 & 52,23 & 50,17 \\
\hline Ізолейцин & 40,00 & 51,55 & 42,27 \\
\hline Фенілаланін+тирозин & 60,00 & 91,06 & 70,45 \\
\hline Лейцин & 70,00 & 71,13 & 10,31 \\
\hline Триптофан & 10,00 & 11,34 & 373,88 \\
\hline $\begin{array}{c}\text { Сумарна масова частка } \\
\text { НАК, мг/100 г білка }\end{array}$ & 350 & 405,15 & \\
\hline
\end{tabular}

У результаті відбувається зниження відсоткового вмісту амінокислот. Найбільше зниження спостерігається у вмісті ізолейцину $(51,55$ мг в контролі та 42,27 мг в дослідному зразку) та у групи амінокислот фенілаланін-тирозин (91,06 мг в контрольному зразку проти 78 мг в оброблювальному зразку). Найменшого впливу зазнали такі амінокислоти, як треонін $(48,45$ мг в контролі та 48,11 в дослідному зразку) й амінокислоти лейцин (71,13 мГ в контролі та 70,45 мг в дослідному зразку).

Далі було розраховано амінокислотний СКОР (відношення скору білка продукту до скору білка етанолу) есенціальних амінокислот і встановлено, що показники СКОРу лізину, треоніну, валіну, ізолейцину, фенілаланіну, 
тирозину, лейцину й триптофану перевищують $100 \%$, тоді як для метеоніну та цистеїну цей показник становить, відповідно, 97,20 та 89,35, з чого можна зробити висновок, що ці амінокислоти є лімітуючі.

Результати розрахунків амінокислотних СКОРів представлені в табл. 4.

\section{Таблиия 4. Амінокислотний СКОР молока}

\begin{tabular}{|c|c|c|}
\hline Найменування незамінної & \multicolumn{2}{|c|}{ Амінокислотний СКОР, \% для сироватки молочної } \\
\cline { 2 - 3 } амінокислоти (НАК) & Контроль & Оброблене молоко ІЕП \\
\hline Лізин & 144,95 & 137,46 \\
\hline Треонін & 121,13 & 120,27 \\
\hline Метіонін+цистин & 97,20 & 89,35 \\
\hline Валін & 104,47 & 100,34 \\
\hline Ізолейцин & 128,87 & 105,67 \\
\hline Фенілаланін+тиросин & 112,83 & 130,01 \\
\hline Лейцин & 101,62 & 100,64 \\
\hline Триптофан & 109,97 & 103,09 \\
\hline
\end{tabular}

Надлишковий вміст амінокислот використовується організмом на енергетичні потреби, тому для оцінки ступеня використання білка нами було розраховано коефіцієнт різниці СКОРу (КРАС), який є середнім арифметичним надлишків СКОРу незамінних амінокислот відповідно СКОРу лімітуючої амінокислоти.

Розрахунок біологічної цінності зразків здійснювали за формулою М.П. Чернікова.

Рівняння розрахунку біологічної цінності наведено у формулі:

$$
\text { БЦ }=100-\text { КРАС, \% }
$$

Дані з розрахунку наведені на рис. 3 .

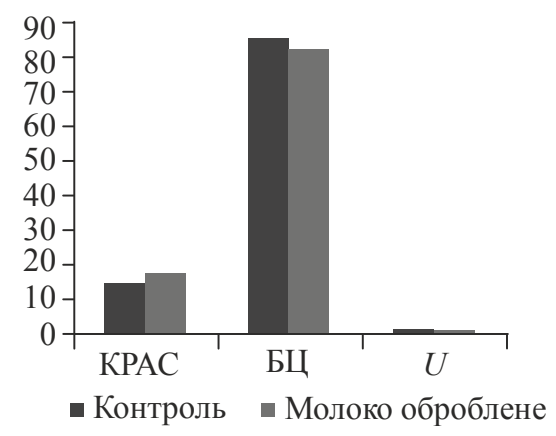

Рис. 3. Показники біологічної цінності білків

Для оцінки збалансованості незамінних амінокислот відносно еталонного білка розраховували коефіцієнт утилітарності $(U)$ :

$$
U=A C_{\min } \frac{\sum_{j=1}^{8} H A K_{e k}}{\sum_{j=1}^{8} H A K_{k}},
$$


де $A C_{\min }$ - мінімальний зі скорів незамінних амінокислот; $\sum_{j=1}^{8} H A K_{e k}-$ сумарний вміст незамінних амінокислот у білку еталону, мг/г білка; $\sum_{j=1}^{8} H A K_{k}-$ сумарний вміст незамінних амінокислот у білку продукту, мг/г.

\section{Висновок}

Досліджено амінокислотний склад обробленого IЕП полями незбираного молока та встановлено, що оброблене молоко містить усі незамінні амінокислоти. Визначено, що домінуючою амінокислотою є лізин, а лімітуючою група метеонін+цистин. У результаті порівняння амінокислотного складу досліджуваних зразків з еталонним білком було розраховано коефіцієнт утилітарності, який становить 1,25 і 1,23. Для розрахунку біологічної цінності було визначено коефіцієнт різниці амінокислотного складу. Біологічна цінність обробленого молока становить $82,02 \%$, що є досить високим показником. Доведено, що обробка ІЕП суттєво не впливає на амінокислотний склад обробленого молока. При такій обробці спостерігається незначне зниження всіх амінокислот, але при цьому його біологічна цінність відповідає медикобіологічним вимогам.

\section{Лiтература}

1. Гулий I.C. Електроіскрові технології в харчовій промисловості: перспективи застосування / І. С. Гулий, А.І. Українець, Ю.О. Дашковський [та ін.] // Наукові праці Національного університету харчових технологій. - 2002. — № 13.—С. $34-39$.

2. Бойко Н.И. Высоковольтный генератор импульсов со средней мощностью до 50 кВт для обработки пищевых продуктов / Н.И. Бойко, А.Н. Тур, Л.С. Евдошенко, А.И. Зароченцев, В.М. Иванов // Приборы и техника эксперимента. - 1998. — № 2. - С. 120-126.

3. Бойко Н.И. Установка для обработки текучих продуктов при помощи комплекса высоковольтных импульсных воздействий и результаты исследований / Н.И. Бойко, А.Н. Тур, Л.С. Евдошенко, В.М. Іванов, А.И. Зароченцев, В.В. Рудаков, А.И. Божков // Технічна електродинаміка. — 2001. - № 4. - С.59-63.

4. Бойко Н.И. Технологии, основанные на воздействии сильных импульсных электрических полей // Технічна електродинаміка. Тематичний випуск «Проблеми сучасної електротехніки». - 2002. — Частина 6. - С. $94-99$.

5. Бойко Н.И. Влияние комплекса высоковольтных импульсов и других физических факторов на интенсивность размножения Anabaena flos aquae / Н.И. Бойко, А.И. Божков // Биофизика. - 2002. - Т. 47. - №. 3. - С. 531-538.

6. Zhang Q.H. Engineering aspects of pulsed electric field pasteurization. / Q.H. Zhang, G.V. Barbosa-Canovas, B.G. Swanson // Journal of Food Engineering. (1995). - 25. P. $261-281$.

7. Святненко Р.С. Влияние импульсного электромагнитного поля на жизнеспособность Escherichia coli в модельном растворе молочной сыворотки / Р.С. Святненко // Науковий вісник Львівського національного університету ветеринарної медицини та біотехнологій імені С.3. Гжицького. — 2016. - Т. 18. — № 2-3(68). - С. 125-131. $365 \mathrm{c}$.

8. Смоляр В.И. Рациональное питание / В.И. Смоляр. - Київ : Наук. думка, 1991. - 